\title{
PENURUNAN SKALA NYERI PADA PASIEN POST OPEN REDUCTIONAL INTERNAL FIXATION MENGGUNAKAN RELAKSASI NAFAS DALAM DAN TERAPI MUSIK
}

\author{
Pujiarto \\ Akademi Keperawatan Panca Bhakti Bandar Lampung \\ Email : pujiart_77@yahoo.com
}

\begin{abstract}
ABSTRAK
Fraktur merupakan istilah dari hilangnya kontinuitas tulang, baik yang bersifat total maupun sebagian. Tindakan pembedahan yang sering digunakan untuk menangani masalah fraktur adalah ORIF (Open Reductional Internal Fixation) yang berguna untuk menstabilkan fraktur. Manifestasi klinis yang timbul dari pembedahan ORIF adalah timbulnya perasaan nyeri. Penanganan nyeri dapat dilakukan dengan terapi farmakologis dan non-farmakologis. Relaksasi nafas dalam dan terapi musik merupakan suatu tindakan terapi non-farmakologis. Tujuan dari penelitian ini adalah menganalisa efek dari penerapan relaksasi nafas dalam dan terapi musik terhadap penurunan skala nyeri. Metode dalam penelitian ini adalah studi kasus dengan menggunakan 2 sampel penelitian dengan cara pengambilan data melalui wawancara, observasi, dan dokumentasi kemudian dilakukan analisa data dengan mengungkapkan fakta selanjutnya dikaitkan dengan teori dan penelitian sebelumnya. Hasil dalam penelitian ini menunjukan bahwa relaksasi nafas dalam dan terapi musik dapat menurunkan skalanyeri pada kedua responden. Berdasarkan hasil penelitian relaksasi nafas dalam dan terapi musik dapat dijadikan sebagai salah satu manajemen nyeri untuk masalah nyeri pada pasien post ORIF ekstremitas bawah yang menjalani perawatan.
\end{abstract}

Kata kunci: Fraktur Ekstremitas Bawah, Nyeri, Open Reductional Internal Fixation (ORIF), Relaksasi Nafas Dalam, Terapi Musik

\begin{abstract}
Fracture is a term of loss of bone continuity, both total and partial. Surgical actions that are often used to deal with fracture problems are ORIF (Open Reductional Internal Fixation) which is useful for stabilizing fractures. Clinical manifestations arising from ORIF surgery are the onset of feeling of pain. Pain management can be done with pharmacological and non-pharmacological therapy. Deep breath relaxation and music therapy are non-pharmacological therapeutic measures. The aim of this study is to analyze the effects of applying deep breath relaxation and music therapy on decreasing pain scale. The method in this study is a case study by using 2 samples research by taking data through interviews, observations, and documentation and then analyzing the data by revealing the facts then associated with previous theories and research. The results in this study show that deep breathing relaxation and music therapy can reduce scalability in both respondents. Based on the results of deep breath relaxation research and music therapy can be used as one of the pain management for pain problems in post ORIF patients with lower extremities undergoing treatment.
\end{abstract}

Keywords: Lower extremity fracture, Pain, Open reductional and internal fixation (ORIF), Deep breath relaxation, Music therapy 


\section{PENDAHULUAN}

Fraktur adalah terputusnya kontinuitas tulang, retak atau patahnya tulang yang utuh, yang biasadisebabkan oleh trauma/rudapaksa atau tenaga fisik yang ditentukan jenis dan luasnya trauma (Lukman dan Ningsih, 2009). World Health Organization (WHO) mencatat pada tahun 2011-2012 terdapat1,3 juta orang menderita fraktur akibat kecelakaan lalu lintas (Noorisa, et al, 2017). Di Indonesia sendiri fraktursering disebabkan oleh cidera seperti terjatuh, kecelakaan lalu lintas dan trauma tajam/tumpul sebanyak 5,8\% (Balitbang Kemenkes RI, 2013). Beberapa kasus fraktur di Indonesia, jumlah fraktur pada ekstremitas bawah akibat kecelakaan memiliki prevalensi yang paling tinggi diantara fraktur lainnya yaitu sekitar 46,2\% (Noorisa, et al, 2017).

Penanganan fraktur dapat dilakukan melalui beberapa prosedur seperti operasi atau tanpa operasi meliputi imobilisasi, reduksi dan rehabilitasi. Prosedural yang sering digunakan untuk penatalaksanaan fraktur ialah reduksi dengan cara memasang fiksasi internal maupun fiksasi eksternal yang menggunakan sekrup, plate atau kombinasi keduanya. Tindakan pembedahan yang sering digunakan untuk menangani masalah fraktur adalah ORIF (Open Reductional Internal Fixation) yang berguna untuk menstabilkan fraktur.
Manifestasi yang timbul akibat pembedahan ORIF salah satunya adalah nyeri. Nyeri adalah pengalaman emosional dan sensori yang tidak meyenangkan yang berhubungan dengan risiko atau aktual kerusakan jaringan (Kneale, 2011). Efek samping yang ditimbulkan dari nyeri pasca pembedahan yaitu memanjangnya waktu pemulihan, terhambatnya ambulasi dini, penurunan fungsi sistem dan terhambatnya discharge planning (Novita, 2012).

Ada sejumlah terapi yang dapat digunakan dalam menurunkan atau mengatasi nyeri yaitu dengan cara terapi farmakologis dan terapi non farmakologis. Terapi farmakologis menggunakan obat-obatan analgetik dengan cara berkolaborasi dengan tenaga medis yang lain. Sedangkan terapi non farmakologis yaitu dengan menggunakan cara teknik relaksasi dan distraksi seperti terapi relaksasi dengan contoh teknik musik, teknik relaksasi otot, teknik massage, dan aromaterapi serta teknik nafas dalam. Namun dalam hal menurunkan nyeri menggunakan terapi farmakologis dengan obat analgetik dapat menimbulkan ketergantungan terhadap obat dan juga akan merugikan pasien dalam segi ekonomi (Novita, 2012). 
Salah satu teknik yang sering digunakan untuk menurunkan nyeri pada pasien adalah menggunakan teknik relaksasi nafas dalam. Menurut Andarmoyo (2013)

Relaksasi nafas dalam adalah suatu tindakan untuk membebaskan mental dan fisik dari ketegangan dan stress sehingga dapat meningkatkan toleransi. Selain relaksasi nafas dalam, terapi musik juga dapat menjadi salah satu pilihan untuk menurunkan nyeri. Terapi musik adalah suatu proses menggabungkan antara aspek penyembuhan musik itu sendiri dengan kondisi dan situasi seperti fisik, emosi, spiritual, mental, kognitif dan kebutuhan sosial seseorang (Natalina, 2013).

Penelitian yang dilakukan oleh Utomo, et al (2015) yang meneliti efektifitas antara terapi musik religi dan slow deep breathing relaxation dengan slow deep breathing relaxation terhadap intensitas nyeri pada pasien post operasi bedah mayor di RSUD Ungaran. Hasil penelitian pada kelompok eksperimen setelah diberikan relaksasi nafas dalam dan musik religi menjadi rata-rata 2,88 , sedangkan pada kelompok yang diberikan relaksasi nafas dalam setelah diberikan relaksasi nafas dalam turun menjadi 3,41. Dari hasil tersebut dapat disimpulkan bahwa musik religi dan nafas dalam lebih efektif dalam menurunkan nyeri daripada relaksasi nafas dalam saja.
Dari penjelasan diatas, peneliti tertarik untuk meneliti asuhan keperawatan pada pasien post ORIF ekstremitas bawah dengan masalah keperawatan nyeri akut menggunakan teknik relaksasi nafas dalam dan terapi musik di ruang Gelatik Rumah Sakit Dr. H. Abdul Moeloek Provinsi Lampung.

\section{METODOLOGI}

Desain penelitian yang digunakan dalam penelitian ini adalah studi kasus. Populasi pada penelitian ini adalah pasien post ORIF ekstremitas bawah yang dirawat di ruang Gelatik RSAM provinsi Lampung pada bulan Juni - Juli 2018. Menggunakan sample sebanyak dua orang responden yang memenuhi kriteria inklusi.

Metode pengambilan data dilakukan melalui wawancara, observasi dan dokumentasi. Instrumen yang digunakan untuk melakukan terapi musik adalah mp4 yang berisi lagu religidan dengan menggunakan headset, serta untuk mengukur skala nyeri menggunakan Numeric Rating Scale (NRS), serta SOP relaksasi nafas dalam dan terapi musik.

Pengumpulan data dilakukan selama 3 hari setelah mendapatkan pasien, sebelum memberikan intervensi, dilakukan pengukuran skala nyeri menggunakan numeric rating scale 
(NRS) kemudian dilakukan intervensi relaksasi nafas dalam dan terapi musik selama kurang lebih 15 menit. Setelah pemberian intervensi klien diberikan waktu istirahat selama 10 menit.

Penelitian ini dilakukan pada bulan Juni Juli 2018. Data yang terkumpul dianalisis dengan membandingkan hasil penelitian, fakta dilapangan dan teori. Tujuannya untuk mengetahui perbedaan antara skalanyerisebelum dan sesudah diberikan relaksasi nafas dalam dan terapi musik. Berdasarkan segi pendidikan kedua responden berada pada pendidikan yang sama yaitu SMA, kedua responden menderita jenis frakturfemur. Berdasarkan segi pekerjaan responden pertama bekerja sebagai petani, dan responden kedua belum bekerja.

Skala nyeri yang diperoleh oleh kedua responden sebelum diberikan intervensi berada pada skala nyeri sedang (5) pada responden pertama, dan skala nyeri sedang a. untuk responden kedua. Pada hasil post test hari ketiga kedua responden mengalami penurunan skala nyeri nyeri ringan (2) untuk responden pertama dan skala nyeri sedang (4) untuk responden kedua. Berikut ini data hasil pengukuran skala nyeri sebelum dan sesudah diberikan relaksasi nafas dalam dan terapi musik pada kedua responden :
Penelitian ini diterapkan etika penelitian berupa prinsip beneficence, respect human of dignity, dan justice (Notoatmodjo, 2010)

\section{HASIL}

Distribusi data demografi responden berada pada rerata usia 20 tahun.

Tabel 1 Hasil pengukuran skala nyeri sebelum dan sesudah diberikan teknik relaksasi nafas dalam dan terapi musik di ruang Gelatik RSUD Dr. H. Abdul Moeloek Provinsi Lampung

\begin{tabular}{ccccccccc}
\hline & \multicolumn{8}{c}{ Hasil penerapan } \\
\cline { 2 - 8 } Hari & \multicolumn{9}{c}{ Tn. B } & \multicolumn{5}{c}{ Tn. Y } \\
\cline { 2 - 8 } & Pre & \multicolumn{3}{c}{ Post } & Pre & \multicolumn{4}{c}{ Post } \\
\cline { 2 - 9 } & 11. & 19. & 11. & 19. & 11. & 19. & 11. & 19. \\
& 30 & 30 & 30 & 30 & 30 & 30 & 30 & 30 \\
\hline & 5 & 5 & 5 & 4 & 6 & 6 & 6 & 5 \\
2 & 5 & 4 & 4 & 3 & 6 & 5 & 5 & 4 \\
3 & 4 & 3 & 3 & 2 & 5 & 5 & 4 & 4 \\
& & & & & & & & \\
\hline
\end{tabular}

\section{PEMBAHASAN}

Dari data kedua responden didapatkan usia pada responden adalah Tn. B berusia 20 tahun dan Tn. Y berusia 21 tahun yang dikategorikan pada dewasa muda yang merupakan usia produktif. Berdasarkan penelitian Desiartama dan Aryana (2017) menyebutkan bahwa angka terjadinya fraktur lebih banyak terjadi pada usia 15-35 tahun yang merupakan usia produktif dikarenakan aktifitas yang tinggi dan mobilitas yang tinggi dari individu dalam kelompok usia produktif. 
Kedua responden sama-sama berjenis kelamin laki-laki, hal ini menunjukan bahwa pasien post operasi ORIF yang menjadi responden di ruang rawat inap penelitian yang dilakukan oleh Desiartama dan Aryana (2017) bahwa fraktur lebih sering dialami laki-laki sebanyak 69,1\% dibandingkan wanita hal ini dikarenakan karena laki-laki lebih sering beraktifitas diluar rumah seperti bekerja, berolahraga dan berkendara selain itu laki-laki juga mempunyai perilaku mengemudi lebih cepat dibandingkan wanita.

Kedua responden sama-sama mengalami fraktur femur akibat kecelakaan lalu lintas, hal ini sesuai dengan penilitian Desiartama dan Aryana (2017) yang menyebutkan bahwa fraktur femur lebih banyak disebabkan karena kecelakaan lalu lintas akibat mobilitas dan aktivitas yang tinggi.

Kedua responden sama-sama mengalami nyeri pada tingkat sedang (skala 4-6) setelah dioperasi ORIF, hal ini disebabkan karena kerusakan jaringan lunak yang diakibatkan dari prosedur pembedahan ORIF yang dilakukan. Hal ini sesuai dengan penelitian Ismonah et al (2015) yang menyebutkan bahwa pasien pasca pembedahan ORIF sering melaporkan tingkat nyeri pada hari 0-3 setelah pembedahan pada tingkatan sedang yaitu pada skala 4-6.
Efek samping yang disebabkan oleh nyeri pasca pembedahan menyebabkan kecemasan pada kedua responden untuk menggerakan kaki yang mengalami pembedahan ORIF dikarenakan takut merasakan nyeri. Hal ini sesuai dengan penelitian yang dilakukan oleh Novita (2012) yang menyatakan bahwa efek samping dari nyeri pembedahan dapat menghambat ambulasi dini.

Berdasarkan data yang didapat melalui pengkajian nyeri sebelum pemberian relaksasi nafas dalam dan terapi musik pada Tn. B adalah nyeri sedang (skala 5) dan Tn. Y adalah nyeri sedang (skala 6) hal ini sama dengan yang diungkapan oleh Ismonah et al (2015) yang menyebutkan bahwa pasien pasca pembedahan ORIF sering melaporkan setelah pembedahan pada tingkatan sedangyaitu pada skala 4-6.Nyeri adalah pengalaman emosional dan sensori yang tidak meyenangkan yang berhubungan dengan risiko atau aktual kerusakan jaringan (Kneale, 2011).

Dari kedua klien dapat dilihat setelah dilakukan relaksasi nafas dalam dan terapi musik menunjukkan perubahan skala nyeri seperti pada Tn. B sebelum pemberian relaksasi nafas dalam dan terapi musik skala nyeri klien adalah nyeri sedang dengan skala 5 dan pada hari ketiga menjadi 2 nyeri ringan dan pada Tn. Y pada hari pertama klien mengalami nyeri sedang pada skala 6 dan pada hari ke-tiga menjadi 4 nyeri sedang. 
Tn. Y tidak mengalami penurunan tingkat nyeri dari sedang ke ringan seperti yang terjadi pada Tn. B, hal ini disebabkan olehSaat dilakukan pemberian relaksasi nafas dalam dan terapi musik Tn. B mendapatkan dukungan dari keluarga yang membuat Tn. B menjadi tenang dan termotivasi dalam melakukan relaksasi nafas dalam dan mendengarkan musik dengan fokus, klien tampak tidak terlalu cemas saat melakukan relaksasi nafas dalam dan terapi musik. Sedangkan Tn. Y ketika pemberian relaksasi nafas dalam dan terapi musik tidak mendapat dukungan keluarga yang membuat Tn. Y kurang termotivasi dalam melakukan relaksasi nafas dalam dan terapi musik. Tn. Y ketika mendengarkan musik yang diberikan tampak seperti gelisah dan tidak begitu tenang. Klien masih tampak merasakan cemas dengan keadaannya. Berdasarkan data tersebut membuktikan bahwa dukungan keluarga dan tingkat kecemasan mempengaruhi penurunan nyeri seperti yang diungkapkan oleh (Haqiki, 2013) bahwa dukungan keluarga dapat memberikan rasa senang, rasa aman, rasa nyaman, dan dapat mempengaruhi kesehatan jiwa dan dapat meningkatkan semangat hidup dan menurunkan kecemasan pasien serta menguatkan komitmen pasien dalam menjalani pengobatan.
Kecemasan menurut Lubis (2014) memiliki hubungan yang signifikan dengan nyeri meskipun umum diyakini bahwa kecemasan akan meningkatkan persepsi nyeri, mungkin tidak seluruhnya benar dalam semua keadaan. Namun kecemasan yang relevan atau berhubungan dengan nyeri dapat meningkatkan persepsi pasien terhadap nyeri.

Hasil penurunan nyeri setelah diberikan relaksasi nafas dalam dan terapi musik ini hasil ini sesuai dengan penelitian yang dilakukan oleh Utomo, dkk (2015) pada pasien pasca pembedahan mayor di RSUD Ungaran membuktikan bahwa terapi musik religi di kombinasi dengan teknik relaksasi nafas dalam lebih efektif menurunkan nyeri dibandingkan hanya menerapkan teknik relaksasi nafas dalam saja.

Peneliti membuktikkan bahwa adanya penurunan tingkat nyeri pada pasien setelah diberikan relaksasi nafas dalam dan terapi musik. Menurut Utomo, et al (2015) Pemberian relaksasi nafas dalam merupakan salah satu keadaan yang mampu merangsang tubuh untuk mengeluarkan opioid endogen sehingga terbentuk sistem penekanan nyeri yang akhirnya akan menyebabkan penurunan nyeri dan mendengarkan musik dala keadaan akut dapat memberikan hasil yang sangat efektif dalam upaya mengurangi nyeri. 
Hasil penelitian ini juga sesuai dengan penelitian Karendehi, et al (2015) pada pasien pasca operasi menggunakan terapi musik untuk menurunkan tingkat nyeri, penelitian ini mendapatkan hasil yang menyatakan bahwa skala nyeri sebelum diberikan musik pada kelompok perlakuan dan tanpa musik pada kelompok kontrol adalah sama dengan mean 5,07, dan setelah di berikan terapi musik sama dengan 3,06. Hal ini membuktikan ada pengaruh pemberian terapi musik terhadap skala nyeri akibat perawatan luka bedah pada pasien pasca operasi.

\section{KESIMPULAN}

Simpulan pada penelitian ini adalah

a. Sebelum dilakukan relaksasi nafas dalam dan terapi musik, Tn. B mengalami nyeri sedang (skala 5) dan Tn. Y mengalami nyeri sedang (skala 6).

b. Setelah dilakukan relaksasi nafas dalam dan terapi musik, Tn. B mengalami penurunan nyeri menjadi nyeri ringan (skala 2) dan Tn. Y mengalami penurunan menjadi nyeri sedang (skala $4)$.

c. Pemberian relaksasi nafas dalam dan terapi musik berpengaruh dalam menurunkan tingkat nyeri selama dirawat dirumah sakit.

\section{KEPUSTAKAAN}

Andarmoyo. (2008). Teknik Prosedural Keperawatan Konsep dan Aplikasi Kebutuhan Dasar Klien. Salemba Medika. Jakarta.

Badan Penelitian dan Pengembangan Kesehatan Kementerian Kesehatan RI / Balitbang Kemenkes RI. (2013). Riset Kesehatan Dasar. Kementerian Kesehatan Republik Indonesia. Jakarta.

Desiartama, A, dan I G N W, Aryana. (2017). Gambaran Karakteristik Pasien Fraktur Femur Akibat Kecelakaan Lalu Lintas pada Orang Dewasa di Rumah Sakit Umum Pusat Sanglah Denpasar Tahun 2013. E-Jurnal Medika. 06 (05) : 1-4.

Haqiki, S. A. N. (2013). Hubungan Dukungan Keluarga dengan Tingkat Kecemasan Pasien Pre Operasi di Ruang Perawatan Bedah Baji Kamase 1 dan 2 Rumah Sakit Labuang Baji Makassar. Skripsi. Fakultas Ilmu Kesehatan Universitas Islam Negeri Alauddin Makassar. Makassar.

Ismonah., D. A. Cahyaningrum, dan M. S. Arif. (2015). Pengaruh Slow Deep Breathing Terhadap Intensitas Nyeri Pasien Post Orif di RS Telogorejo Semarang. Jurnal Ilmu Keperawatan dan Kebidanan.

Karandehi, D. S., S. S. J. Rompas, dan H. Bidjuni. (2015). Pengaruh Pemberian Musik Terhadap Skala Nyeri Akibat Perawatan Luka Bedah pada Pasien Pasca Operasi di Ruang Perawatan Bedah Flamboyan Rumah Sakit TK. III 07.06.01 R.W Mongsidi Manado Tahun 2015. E Journal Keperawatan. 3(2): 1-8.

Kemenkes RI. (2013). Profil Kesehatan Indonesia 2012. Jakarta: Kemenkes

Kneale, J. D dan P. S. Davis. (2011). Keperawatan Ortopedik \& Trauma. Edisi Kedua. EGC. Jakarta.

Lubis, M. (2014). Hubungan Tingkat Kecemasan dengan Persepsi Nyeri pada Pasien Apendisitis di Ruang Bedah Rumah Sakit Embung Fatimah Kota Batam. 
Lukman, dan N. Ningsih. (2009). Asuhan Keperawatan pada Klien dengan Gangguan Sistem Muskuloskeletal. Salemba Medika. Jakarta.

Natalina, D. (2013). Terapi Musik Bidang Keperawatan. Edisi Pertama. Mitra Wacana Media. Jakarta.

Noorisa, R., D. Apriliawati., A. Aziz, dan S. Bayusentosa. (2017). The Characteristic Of Patients With Femoral Fracture In Department Of Orthopaedic And Traumatology RSUD Dr. Soetomo Surabaya 20132016. Journal of Orthopaedicand Traumatology Surabaya Media. 06 (01): 1-10.

Notoatmodjo, S. (2010). Metodologi Penelitian Kesehatan. Rineka Cipta. Jakarta
Novita, D. (2012). Pengaruh Terapi Musik terhadap Nyeri Post Operasi Open Reductional and Internal Fixation (ORIF) di RSUD Dr. H. Abdul Moeloek Provinsi Lampung. Tesis. Fakultas Ilmu Perawatan Program Pascasarjana Magister Ilmu Keperawatan Kekhususan Keperawatan Medikal Bedah Universitas Indonesia. Depok.

Utomo, W., Y. Armiyati, dan M. S. A. SN. (2015). Efektifitas antara Musik Religi dan Slow Deep Breathing Relaxation dengan Slow Deep Breathing Relaxation terhadap Intensitas Nyeri pada Pasien Post Operasi Bedah Mayor si RSUD Ungaran 